\author{
Valerii F. Hraniak ${ }^{1}$, Vasyl V. Kukharchuk ${ }^{1}$, Volodymyr Y. Kucheruk ${ }^{1}$, \\ Samoil Sh. Katsyv ${ }^{1}$, D.Zh. Karabekova ${ }^{2}$, A.K. Khassenov ${ }^{2}$ \\ ${ }^{1}$ Vinnitsa national technical university, Ukraine \\ ${ }^{2}$ Ye.A. Buketov Karaganda State University, Kazakhstan \\ (E-mail: titanxp2000@ukr.net)
}

\title{
Mathematical model of capacitance micromechanical accelerometer in static and dynamic operating modes
}

\begin{abstract}
Monitoring and early diagnosis systems, on which the protection function of both hydroturbines and auxiliary power equipment rely, are becoming increasingly relevant. One of the most promising methods of technical control and diagnostics of hydo units is the analysis of their vibro-acoustic characteristics. But a significant technical problem that arises in the construction of such systems is the limited use of known sensors of vibration velocity and vibration displacement due to the fact that the rotary speed of hydro units is usually below the lower limit of operation of sensors of this type. One of the promising ways to solve this problem is using capacitive micromechanical accelerometers. However, the existing mathematical models describing this type of accelerometers have low accuracy, which limits their practical using. The mathematical models of the capacitive micromechanical accelerometer for static and dynamic modes of operation are developed in this article. It was established that this accelerometer has a constant sensitivity, therefore its static characteristic is linear. It is shown that in the dynamic mode of operation of a capacitive micromechanical accelerometer has a dynamic error component, the cause of which is its own displacement of the moving part of the sensor, which is due to the inertial properties of the moving part and elastic properties of stretch marks. The mathematical dependence of the absolute dynamic error of the capacitive micromechanical accelerometer is obtained, the removal of which from the measurement results will improve the accuracy of the specified primary measuring transducer.
\end{abstract}

Keywords: capacitive micromechanical accelerometer, mathematical model, dynamic mode of operation, static mode of operation, dynamic error.

\section{Introduction}

As of today, a strong tendency has developed to construct systems for technical inspection and diagnostics of electric power machines based on analysis of their vibroacoustic characteristics. This is due to both a high informational content of this parameter and with the opportunity to measure the said parameter directly in electric machine's operational mode without the need to intervene into its design $[1,2]$. However, a significant technical problem that arises during construction of systems for inspection and diagnostics of lowspeed electric machines (including hydropower units of HPPs and PSPPs) lies in a considerable limitation on the use of known sensors of vibration velocity and vibration displacement due to the fact that rotary revolution speed in such machines is normally lower than the lower boundary of operation for sensors of this type [3]. One of the approaches to solution of this problems lies in the use of accelerometerers. That said, when analyzing technical characteristics of known vibration accelerometers [4], one of the most promising ones to be used in systems for technical inspection and diagnostics of low-speed electric machines is a capacitance micromechanical accelerometer. This can be explained by its low inertial mass (of some $0.1 \mathrm{mcg}$ ), high overload capability (of some 10,000 g without sensor's breakdown) and a wide frequency range of operation (from static acceleration to single units of kilohertz). However, it follows from analytical review of accompanying engineering documentation and scientific-and-technical literature $[4,5]$ that existing mathematical models describing this variety of accelerometers are quite approximate. So, development of mathematical model of this primary measuring transformer is a relevant research-and-application task of considerable practical significance.

\section{Setting the task}

The sensing element of micromechanical capacitance accelerometer is conventionally presented as a structural diagram shown in fig. 1. It represents a differential condenser-type structure with an air dielectric. Condenser's electrodes are cut from a flat piece of polysilicon some $2 \mathrm{mcm}$ thick. This condenser's stationary electrodes are represented by simple cantilever bars situated at the height of some $1.3 \mathrm{mcm}$ from crystal's 
surface in the air on polysilicon anchor columns welded to the crystal at the molecular level. The sensor's design comprises more than 50 such sensing elements (elementary cells). Acceleration sensor's inertial mass during the sensor's accelerated movement becomes displaced in relation to the crystal's other part. Its fingerlike protrusions form condenser's movable electrode. Both sides of this structure rest against anchor columns. Stretches that hold the inertial mass play the role of a mechanical spring of constant elasticity that restricts mass motion and ensures its return to the initial position. Displacement of movable part in relation to the stationary one causes change in capacity of each elementary cell of capacitance micromechanical accelerometer, which corresponds to the primary measuring transformation of «acceleration into capacity» type [6].

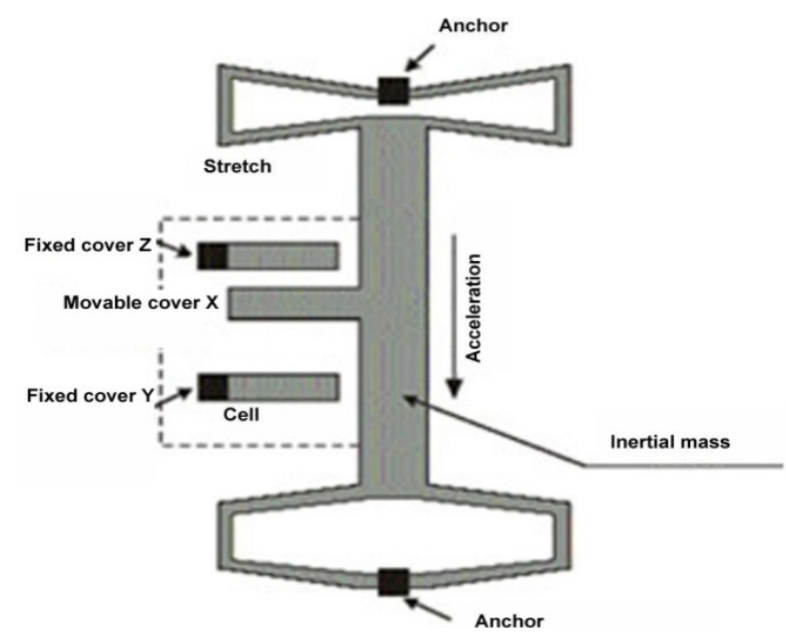

Figure 1. Structural diagram of capacitance micromechanical accelerometer's sensing element

The next measuring transformation being implemented during acceleration measurement using capacitance micromechanical accelerometer is transformation of "capacity into voltage» type, which in sensors of ADXLxxx series by Analog Devices is implemented by devices located immediately in the sensor's housing, in their essence being its component part $[7,8]$.

The aim of the work is to obtain a high-precision mathematical model that would describe the relationship between the input and output signals of the accelerometer in static and dynamic modes. The need for such the model is due to the using of the measuring transducer, as part of the technical diagnostic system of ow-speed electric machines (hydro units), in real time of their operation. Therefore, let us describe the highlighted measuring transformations in mathematical terms.

\section{Analysis of approaches to problem solution}

Under acceleration, inertia force may be determined based on Newton's second law as follows [9]:

$$
F_{e i}=m_{e} \cdot a,
$$

where $m_{e}$ - the mass of the elementary cell's movable part; $a$ - the acceleration of the elementary cell's movable part

Inertia force is counterbalanced by the spring's counter force

$$
F_{n p}=k \cdot X,
$$

where $X$ - mass displacement in relation to the equilibrium position; $\mathrm{k}$ - elasticity coefficient of elementary cell's stretches.

Having equated the inertia force and spring's counter force that is present in static mode of operation (measurement of uniform acceleration), we will obtain

$$
a=\frac{k}{m_{e}} X=S_{e} \cdot X
$$

where $S_{e}$ - sensitivity of capacitance micromechanical accelerometer's elementary cell

It follows from (3) that sensitivity of capacitance micromechanical accelerometer's elementary cell is a constant parameter, the value of which depends on sensor's structural parameters $\left(k\right.$ and $\left.m_{e}\right)$. 
Since displacement of inertial mass takes place in the plane of polysilicon film, the sensor's sensitivity axis also lies in this plane and, correspondingly, it is parallel to the plane of printed board, on which the sensing element is situated.

At rest (constant-speed movement), all «fingers» of movable electrode, thanks to stretch's action, are located at the same distance from the stationary electrode's couple of «fingers». At any acceleration, movable electrodes approach to one of assemblies of stationary electrodes and move away from others. As a result, relative displacement becomes nonuniform, and capacity between movable electrode and each of movable electrodes changes in proportion to vibration acceleration. Id est:

$$
\Delta C_{e}=\alpha \cdot X,
$$

where $\Delta C_{e}$ - the change of capacity of the sensor's elementary cell.

Since capacitance micromechanical sensor contains $n$ elementary cells being identical by their structure, located in the same plane, with their capacities connected between each other in parallel, we can write as follows:

$$
\varepsilon=a_{1}=a_{2}=\ldots=a_{n},
$$

where $\varepsilon-$ the acceleration measured by the sensor (input physical value).

$$
\Delta C=\sum_{i=1}^{n} \Delta C_{e i}
$$

where $\Delta C$ - the change in capacity of capacitance micromechanical accelerometer.

$$
m=\sum_{i=1}^{n} m_{e i},
$$

where $m$ - the mass of the movable part of capacitance micromechanical accelerometer.

Such being the case, having assumed the averaged value of elasticity coefficient of stretches of its elementary cells as the elasticity coefficient of stretches of capacitance micromechanical accelerometer, we will obtain:

$$
\varepsilon=\frac{k}{m} X
$$

Considering that, according to stated technical characteristics of sensors of ADXLxxx series by Analog Devices, technical characteristics of which we will use from now on, the time constant of measuring transformers of «capacity into voltage» type is considerably less than the time constant of inertial mass, and the change in value of output voltage of the sensor (after transformers of «capacity into voltage») is proportionate to the change in capacity of sensing element $[7,8]$, we will obtain:

$$
U=\beta \cdot \Delta C=\beta \cdot \gamma \cdot X=\frac{\beta \cdot \gamma \cdot m}{k} \varepsilon,
$$

where $\beta$ - proportionality coefficient of capacity transformation into increase of the sensor's output voltage; $\gamma$ - proportionality coefficient of transformation of the sensor's movable part displacement in relation to stationary one into capacity increase.

Such being the case, the sensor's sensitivity may be determined as follows:

$$
S=\frac{d U}{d \varepsilon}=\frac{\beta \cdot \gamma \cdot m}{k}
$$

The sensor's static characteristics for sensitivity of $0.1 \mathrm{~V} \cdot \mathrm{sq}$. $\mathrm{s} / \mathrm{m}$, which is typical for sensors of ADXL320 series by Analog Devices [7] is shown in fig. 2

Expression (10) is the mathematical model of capacitance micromechanical accelerometer in the static mode of operation. However, since static mode of operation is rather an exclusive than a standard mode in the systems for technical inspection and diagnostics of low-speed electric machines and this sensor was designed to work in slightly other measuring systems, for which only the normalization of the dynamic component of the error was sufficient, in order to solve the task set one should obtain the mathematical model that would take into account dynamic specificities of operation of accelerometers of this type.

As has been noted above, the change in capacity of capacitance micromechanical accelerometer is linearly connected with displacement of the sensor's movable part. Since the sensor's movable part is cushioned on stretches, in case of its destabilization own damped oscillations will arise, overlaying the forced displacement of equilibrium point. Id est:

$$
X(t)=X_{b}(t)+X_{n p}(t)
$$


where $X(t)$ - the dependency of general displacement of the sensor's movable part in relation to the stationary one; $X_{n p}(t)$ - the forced component of general displacement of the sensor's movable part, which is determined by external influence (sensor's acceleration); $X_{b}(t)$ - own displacement of the sensor's movable part in relation to the stationary one determined by own inertial movement.

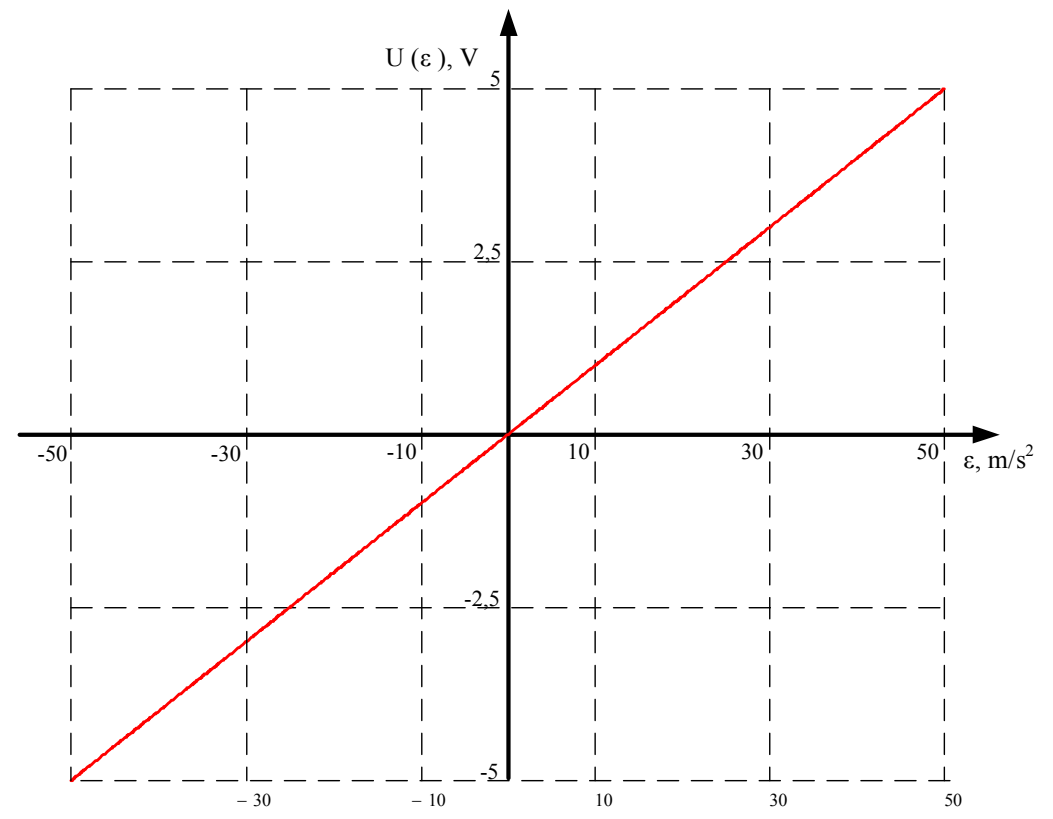

Figure 2. Static characteristics of capacitance micromechanical accelerometer ADXL320

Since forced component of the general displacement of the sensor's movable part is exclusively determined by external influence, then in the absence (compensatedness) of gravitation component's projection onto the measuring axis, which brings an additive error component into an output signal of capacitance micromechanical sensor [10], this may be determined as:

$$
X_{n p}(t)=\frac{m}{k} \varepsilon(t)
$$

In its turn, own component of displacement of the sensor's movable part is determined by presence of «elastic pendulum» mechanical system. So, under the action of constant i-agitation this may be described by expression [11]:

$$
\frac{d^{2} X_{s i}(t)}{d t^{2}}+\frac{P}{m} \frac{d X_{s i}(t)}{d t}+\frac{k}{m} \cdot X_{s i}(t)=0
$$

where $P$ - the coefficient of resistance to displacement of the movable part; $X_{i i}(t)$ - displacement of the sensor's movable part in relation to equilibrium position from i-agitation.

Then general displacement of the sensor's movable part in relation to the stationary one under the action of constant i-agitation will be described by the following nonuniform differential of second order:

$$
\frac{d^{2} X_{i}(t)}{d t^{2}}+\frac{P}{m} \frac{d X_{i}(t)}{d t}+\frac{k}{m} \cdot X_{i}(t)+\frac{m}{k} \varepsilon_{i}=0 .
$$

Since in real-world sensor the inertial resistance coefficient is fairly minor, while stretches have quite a high stiffness [8], the following inequation will be implemented:

$$
\left(\frac{P}{m}\right)^{2}-\frac{4 k}{m}<0
$$

and solution of (15) in relation to $X_{i}(t)$ will look as follows:

$$
X_{6 i}(t)=e^{-\xi \omega_{0} t}\left(A_{i} \cos \left(\omega_{0} t\right)+B_{i} \sin \left(\omega_{0} t\right)\right)+X_{n p},
$$

where $A_{i}$ and $B_{i}$ - the integration constant determined by initial conditions; $\mathrm{X}_{\text {пр }}$ - the coordinate of equilibrium position under resultant of system of forces; $\omega_{0}$ - the cyclic frequency of own oscillations of the sensor's movable part; $\xi$ - the coefficient of proportionality between cyclic frequency of own oscillations and coefficient of their damping. That said: 


$$
\omega_{0}=\sqrt{\frac{k}{m}}
$$

and,

$$
\xi=\frac{P}{2 \sqrt{k \cdot m}},
$$

Then own general displacement of the sensor's movable part, based on its temporal implementation may approximately be found out as follows:

$$
X(t)=\sum_{i=1}^{n} X\left(t-i \cdot T_{\partial}\right)
$$

where $T_{\partial}$ - the system's discretization interval.

Expression (20) enables us to evaluate the experimental value of instantaneous displacement of the sensor's movable part, with application of its interpretations for theoretical analysis of metrological characteristics of capacitance micromechanical sensor being quite complicated. Hence, to solve this problem it is advisable to use the transient characteristics of own displacement of the sensor's movable part in relation to the stationary one $h(t)$ depending on the sensor's acceleration, which may quite easily be calculated based on its passport data. Such being the case, general displacement of the movable part may be determined as follows:

$$
X(t)=\varepsilon(0) \cdot h(t)+\int_{0}^{t} \frac{d \varepsilon(t)}{d t} h(t-\tau) d \tau
$$

We will obtain a typical transient characteristics of capacitance micromechanical accelerometer for sensor ADXL320 by Analog Devices. It follows from the analysis of its passport data that a typical throughput capacity of such an accelerometer type does not exceed $2.5 \mathrm{kHz}$ [7]. Hence, the period of mechanical transient process, with regard to the sampling theorem, may be determined as follows:

$$
t_{n n}=\frac{1}{2 f_{\max }}=\frac{1}{2 \cdot 2500}=0,0002(c),
$$

where $f_{\max }$ - the sensor's throughput capacity.

Considering that actual duration of mechanical transient process is linked to its time constant with the following relationship:

$$
\tau=\frac{1}{5} t_{n n}=\frac{1}{\xi \omega_{0}}=40(\text { м } c),
$$

we will obtain the value of the real part of characteristic equation root that describes the mechanical transient process of the accelerometer's movable part:

$$
\xi \omega_{0}=\frac{10^{5}}{4}=25000\left(c^{-1}\right) .
$$

By substituting (18) and (19) into (24), and having performed some mathematical transformations, we will obtain:

$$
\frac{P}{2 m}=25000\left(c^{-1}\right) \text {. }
$$

Considering that the mass of the movable part of capacitance micromechanical accelerometer is somewhat $1.3 \mathrm{mcg}[6,12]$, the coefficient of resistance to the movable part's displacement will have the value of somewhat $65 \cdot 10^{3} \mathrm{~kg} / \mathrm{s}$. That said, while the elasticity coefficient of elementary cell's stretches has the value of some $1,300 \mathrm{~N} / \mathrm{m}[12]$, then

$$
\omega_{0}=\sqrt{\frac{1,3 \cdot 10^{3}}{1,3 \cdot 10^{-6}}} \approx 31,6 \cdot 10^{2}(\mathrm{pad} / \mathrm{c}) .
$$

In order to calculate (17), let us assume independent initial conditions and forced components that correspond to the input signal that varies according to the Heaviside function. Id est, the sensor's movement starts at zero speed and zero time moment with the acceleration of $1 \mathrm{~m} / \mathrm{sq}$. $\mathrm{s}$, has the direction contrary to positive displacement of the sensor's movable part and continues up to final completion of mechanical tran- 
sient process (has an indefinite duration) without changing the direction of movement. Such being the case, the exciting force to be applied to the sensor's movable part may be determined according to (1):

$$
F_{\text {зр }}=m \cdot a=1,3 \cdot 10^{-6} \cdot 1=1,3 \cdot 10^{-6}(H) .
$$

That said, the new equilibrium position of the movable part may be calculated as follows:

$$
X_{n p}=\frac{F_{3 p}}{k}=\frac{1,3 \cdot 10^{-6}}{1,3 \cdot 10^{3}} \approx 1(\mathrm{HM}) .
$$

Since initial zero conditions are linked to the sensor's previous mode of operation (its zero displacement and speed), then, according to the conditions set forth above, we have:

$$
\left\{\begin{array}{l}
X_{b i}(0)=0, \\
v_{s i}(0)=0 .
\end{array}\right.
$$
pression:

Such being the case, the speed of the sensor's movable part will be described using the following ex-

$$
v_{B i}(t)=\frac{d X_{s i}(t)}{d t}=\omega_{0} e^{-\xi \omega_{0} t}\left(B_{i} \cos \left(\omega_{0} t\right)+A_{i} \sin \left(\omega_{0} t\right)\right)-\xi \omega_{0} e^{-\xi \omega_{0} t}\left(A_{i} \cos \left(\omega_{0} t\right)+B_{i} \sin \left(\omega_{0} t\right)\right)
$$

Having solved the system that includes (17) and (30) taking into account the initial conditions (29), in relation to integration constants for time moment $\mathrm{t}=0$, we will obtain:

$$
\left\{\begin{array}{l}
A \approx-10^{-9}, \\
B \approx-7,91 \cdot 10^{-10} .
\end{array}\right.
$$

Having substituted the value of forced component of the sensor's movable part displacement (28) and integration constants (31 into (17), we will obtain the transient characteristics of capacitance micromechanical sensor ADXL320. Graphic interpretation of this dynamic metrological characteristic is shown in fig. 3.

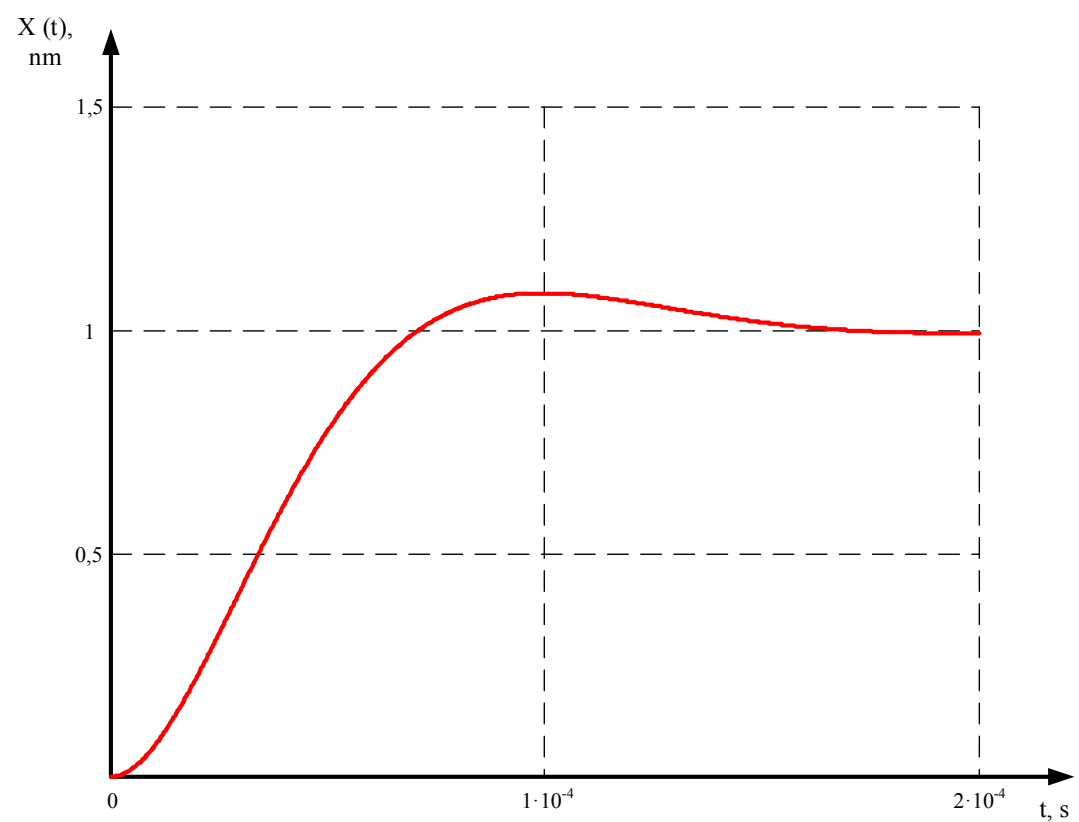

Figure 3. Transient characteristic of capacitance micromechanical accelerometer ADXL320

Taking into account (10), we will obtain the voltage variation function at the sensor's output:

$$
U(t)=\beta \cdot \gamma \cdot X(t) \text {. }
$$

Or having substituted into (32) dependency (9), which is normally used when establishing the equation of transformation of capacitance micromechanical accelerometer:

$$
U(t)=\frac{\beta \cdot \gamma \cdot m}{k}\left(\varepsilon(t)+\Delta_{\partial}(t)\right)=\frac{\beta \cdot \gamma \cdot m}{k} \varepsilon(t)+\frac{\beta \cdot \gamma \cdot m}{k} \Delta_{\partial}(t),
$$

where $\varepsilon(t)$ - the acceleration value being measured; $\Delta_{\partial}(t)$ - the dynamic error that arises as a result of own displacement of the sensor's movable part in relation to the stationary one, conditioned by its inertia. 
Expression (21) with due regard to (9) for a random temporal variation of measuring acceleration may be written as follows:

$$
U(t)=\frac{\beta \cdot \gamma \cdot m}{k}\left(\varepsilon(0) \cdot h(t)+\int_{0}^{t} \frac{d \varepsilon(t)}{d t} h(t-\tau) d \tau\right) .
$$

In its nature, dependency (34) is the mathematical model of capacitance micromechanical accelerometer that describes the dynamic mode of its operation.

Having regard to (33) and (34), we will obtain the expression to evaluate the value of the absolute dynamic error of capacitance micromechanical accelerometer:

$$
\begin{gathered}
\Delta_{\partial}=\frac{\frac{\beta \cdot \gamma \cdot m}{k}\left(\varepsilon(0) \cdot h(t)+\int_{0}^{t} \frac{d \varepsilon(t)}{d t} h(t-\tau) d \tau\right)-\frac{\beta \cdot \gamma \cdot m}{k} \varepsilon(t)}{\frac{\beta \cdot \gamma \cdot m}{k}}= \\
=\varepsilon(0) \cdot h(t)+\int_{0}^{t} \frac{d \varepsilon(t)}{d t} h(t-\tau) d \tau-\varepsilon(t) .
\end{gathered}
$$

\section{Conclusions}

1. Obtained was the mathematical model of capacitance micromechanical accelerometer in the static mode of operation, which allows establishing the unambiguous connection between the value of acceleration of the sensor's housing and the value of its output voltage. It was established that this accelerometer has constant sensitivity, so its static characteristics is linear.

2. Obtained was the mathematical model of capacitance micromechanical accelerometer in the dynamic mode of operation, which allows establishing the unambiguous connection between the value of acceleration of the sensor's housing and the value of its output voltage. It was demonstrated that, in the dynamic mode of operation, this sensor is characterized by dynamic error conditioned by the movable part's inertial properties and elasticity of stretches.

3. Obtained was the mathematical dependency of the absolute dynamic error of capacitance micromechanical accelerometer, withdrawal of which from measurement results allows raising the precision of the said primary measuring transformer.

\section{References}

1 Levitsky, A.S. (2010). Improving efficiency of diagnostics of powerful hydro units due to the use of capacitive meters of mechanical defect parameters. Hydropower of Ukraine, 4, 10-13.

2 Hraniak, V.F., Kukharchuk, V.V., \& Kucheruk, V.Y. et al. (2018). Using instantaneous cross-correlation coefficients of vibration signals for technical condition monitoring in rotating electric power machine. Bulletin of the University of KaragandaPhysics, 1, 72-80.

3 Hraniak, V.F., Kazyv, S.Sh., \& Kukharchuk, V.V. (2017). Correlation approach to determination of weight coefficients of artificial neural network for vibro-diagnostics of hydro units. Bulletin of Academy of Engineering of Ukraine, 4, 100-105.

4 Frieden, J. (2015). Modern sensors. Moscow, Russia: Technosphere.

5 Aleshina, B.S., Veremeenko, K.K., \& Chernomorsky, A.I. (2006). Orientation and navigation of moving objects: modern information technology. Moscow, Russia: PHYSMATLITIS.

6 Kukharchuk, V.V., Vedmitskyi, Y.G., Hraniak, V.F. (2019). Measurement of rotational motion parameters of electromechanical energy converters in transient modes. Vinnytsia, Ukraine: VNTU.

7 Analog Devices. Small and Thin $\pm 5 \mathrm{~g}$ Accelerometer ADXL320. Datasheet, 16.

8 Sysoeva, S. (2006). Car accelerometers. Part 5. The prospective elemental base of surface silicon capacitive MEMS accelerometers, 4, 28-39.

9 Rao, S. S. (2007). Vibration of continuous systems. New York, USA: Jon Wiley \& Sons.

10 Hraniak, V.F., Kukharchuk, V.V., \& Bilichenko, V.V. et al. (2019). Correlation method for calculation of weight coefficients of artificial neural-like networking hydraulic units' diagnostic systems. Proceeding of SPIE. Photonics Applications in Astronomy, Communications, Industry and High-Energy Physics Experiments, 11176, 7.

11 Shcheglova, I.Y., \& Boguslavsky, A.A. (2009). Modeling of oscillatory processes (for example, physical problems). Kolomna, Russia: Kolomna State Pedagogical Institute.

12 Kukharchuk, V.V., Kucheruk, V.Y., Volodarsky, E.T., \& Grabko, V.V. (2013). Fundamentals of metrology and electrical measurements. Kherson, Ukraine: Old-plus. 
В.Ф. Граняк, В.В. Кухарчук, В.Ю. Кучерук, С.Ш. Кацыв, Д.Ж. Карабекова, А.К. Хасенов

\title{
Статикалық және динамикалық жұмыс тәртіптеріндегі сыйымдылық микромеханикалық акселерометрдің математикалық моделі
}

\begin{abstract}
Бақылау және ерте диагностикалау жүйесі үлкен өзектілікке ие болуда, оларға су турбинасы сияқты қосалқы күштік жабдықтарды қорғау функциясы жатады. Гидроагрегаттарды техникалық бақылау мен диагностикалаудың ең перспективалы әдістерінің бірі олардың діріл - акустикалық сипаттамаларын талдау болып табылады. Бірақ мұндай жүйелерді құру кезінде пайда болатын маңызды техникалық мәселе, гидроагрегаттардың роторлық айналу жиілігі әдетте осы типті сенсорлар жұмысының төменгі шегінен аз болғандықтан, діріл жылдамдығы мен дірілді ығыстырудың белгілі сенсорларын қолданудың шектеулілігі болып табылады. Бұл мәселені шешудің перспективалық жолдарының бірі сыйымдылық микромеханикалық акселерометрлерді пайдалану. Алайда, акселерометрлердің осы түрін сипаттайтын қазіргі математикалық модельдер олардың практикалық қолданылуын шектейтін дәлдігі де бар. Жұмыста статикалық және динамикалық жұмыс тәртіптеріне арналған сыйымдылық микромеханикалық акселерометрдің математикалық модельдері әзірленген. Бұл акселерометрдің тұрақты сезімталдығы бар екені анықталды, сондықтан оның статикалық сипаттамасы сызықтық болып табылады. Сыйымдылық микромеханикалық акселерометрдің динамикалық жұмыс режимінде динамикалық құраушы қателігі бар, оның пайда болу себебі датчиктің жылжымалы бөлігінің өздігінен тазартылуы, бұл жылжымалы бөліктің инерциялық қасиеттерімен және созылулардың серпінді қасиеттерімен байланысты. Сыйымдылық микромеханикалық акселерометрдің абсолюттік динамикалық қателігінің математикалық тәуелділігі алынды, оны өлшеу нәтижесінен алу көрсетілген бастапқы өлшеу түрлендіргішінің дәлдігін арттыруға мүмкіндік береді.
\end{abstract}

Кілm сөздер: сыйымдылық микромеханикалық акселерометр, математикалық модель, динамикалық жұмыс тәртібі, статикалық жұмыс тәртібі, динамикалық қателік.

\section{В.Ф. Граняк, В.В. Кухарчук, В.Ю. Кучерук, С.Ш. Кацыв, Д.Ж. Карабекова, А.К. Хасенов \\ Математическая модель емкостного микромеханического акселерометра в статическом и динамическом режимах работы}

\begin{abstract}
Все большую актуальность приобретают системы контроля и раннего диагностирования, на которые полагается функция защиты как гидротурбин, так и вспомогательного силового оборудования. Одним из наиболее перспективных методов технического контроля и диагностики гидроагрегатов является анализ их вибро- и акустических характеристик. Но существенной технической проблемой, возникающей при построении таких систем, является ограниченность применения известных сенсоров виброскорости и вибросмещения, вследствие того, что роторная частота вращения гидроагрегатов обычно ниже нижнего предела работы сенсоров данного типа. Одним из перспективных путей решения этой проблемы является использование емкостных микромеханических акселерометров. Однако существующие математические модели, описывающие этот вид акселерометров, имеют низкую точность, что ограничивает их практическое использование. В работе разработаны математические модели емкостного микромеханического акселерометра для статического и динамического режимов работы. Установлено, что данный акселерометр имеет постоянную чувствительность, поэтому его статическая характеристика является линейной. Показано, что в динамическом режиме работы емкостной микромеханический акселерометр имеет динамическую составляющую погрешности, причиной возникновения которой является собственное перемещение подвижной части датчика, что обусловлено инерционными свойствами подвижной части и упругими свойствами растяжек. Получена математическая зависимость абсолютной динамической погрешности емкостного микромеханического акселерометра, изъятие которой из результатов измерения позволит повысить точность указанного первичного измерительного преобразователя.
\end{abstract}

Ключевые слова: емкостный микромеханический акселерометр, математическая модель, динамический режим работы, статический режим работы, динамическая погрешность. 